\title{
STUDI FENOMENOLOGI TENTANG KOMUNIKASI ANTARPRIBADI ANGGOTA KOMUNITAS ANAK INDIGO INDONESIA
}

\author{
Mochamad Fachri Fauzan ${ }^{1}$, Lucy Pujasari Supratman ${ }^{2}$ \\ Prodi S1 Ilmu Komunikasi Fakultas Komunikasi dan Bisnis Universitas Telkom
}

\begin{abstract}
ABSTRAK
Tuhan menciptakan setiap manusia dengan sempurna, namun tidak dapat dipungkir bahwa ada manusia yang terlahir tidak sempurna dalam bentuk fisik maupun mental. Hal tersebut dapat menjadi sebuah kekurangan ataupun kelebihan bagaimana cara kita memaknai dirinya sendiri, sama halnya seperti anak indigo. Konsep diri merupakan gambaran yang dimiliki seseorang tentang dirinya yang dibentuk melalui pengalaman-pengalaman yang diperoleh dari interaksi dengan lingkungan. Tujuan penelitian ini adalah mengguraikan konsep diri anggota komunitas anak indigo dalam melakukan komunikasi antarpribadi. Penelitian ini dikaitan dengan orientasi motif masa lalu, masa kini, dan masa akan datang. Informan yang terlibat dalam penelitian ini ada lima anak indigo yang tergabung Komunitas Anak Indigo (KAI). Penelitian ini menggunakan metode kualitatif dengan pendekatan fenomenologi. Teknik pengumpulan data yang digunakan dalam penelitian ini adalah dengan cara wawancara mendalam, observasi, dan dokumentasi.Teknik analisis data penelitian ini menggunakan teknik analisis data fenomenologi Van Kaam. Berdasarkan hasil penelitian ini dapat ditarik kesimpulan bahwa anggota Komunitas Anak Indigo menilai dirinya memiliki konsep diri positif dan negatif yang terbentuk berdasarkan pengalaman interaksi dalam oritentasi masa lalu, masa kini, dan masa akan datang. Anggota Komunitas Anak Indigo (KAI) menilai keberadaan mereka dalam Komunitas Anak Indigo (KAI) mengalami perubahan ke arah yang lebih baik dari berbagai aspek kehidupan pribadi para anggota Komunitas Anak Indigo (KAI). Kata Kunci: Komunikasi Antarpribadi, Konsep Diri, Indigo, Motif, Fenomenolog
\end{abstract}

\section{PHENOMENOLOGICAL STUDY OF INTERPERSONAL COMMUNICATION COMMUNITY MEMBERS IN INDIGO CHILDREN}

\begin{abstract}
God created every human being with perfection, but it is undeniable that there are people who are born imperfect in shape physically and mentally. It can be a shortage or excess of how we interpret itself, as well as indigo children. The concept itself is a picture of a person about himself that was formed through the experiences gained from interaction with the environment. The purpose of this study is to describe the self-concept of indigo children community members in conducting interpersonal communication. The purpose of this study is to describe the self-concept of indigo children community members in conducting interpersonal communication. This research orientation are associated with the motive of the past, present, and future. The informant involved in this study were five children with indigo capabilities incorporated within the Community of Indigo Children (KAI). This study used a qualitative method with phenomenological approach. Data collection techniques used in this
\end{abstract}


research is by interview, observation and documentation. This research data analysis techniques using data analysis techniques phenomenology by Van Kaam. Based on these results it can be concluded that the Indigo Children Community members consider themselves to have a positive self-concept and negative formed based on the experience of interaction in open thou the past, present, and future. Community Members Indigo Children (KAI) to assess their presence within the Community of Indigo Children (KAI) to change to the better of the various aspects of the private lives of members of the Community Indigo Children (KAI)

Keywords: Interpersonal Communication, Self-Concept, Indigo, Motive, Phenomenolog

Korespondensi: Mochamad Fachri Fauzan. Universitas Telkom. Jl. Telekomunikasi, Jl. Terusan Buah Batu No.01, Dayeuhkolot, Bandung, Jawa Barat 40257.Email: fachriopuw@ gmail.com

\section{PENDAHULUAN}

Tuhan menciptakan setiap manusia dengan sempurna, namun tidak dapat dipungkir bahwa ada manusia yang terlahir tidak sempurna dalam bentuk fisik maupun mental. Hal tersebut dapat menjadi sebuah kekurangan ataupun kelebihan bagaimana cara kita memaknai dirinya sendiri, sama halnya seperti Indigo. Indigo pertama kali diperkenalkan pada buku "Understanding Your Life Through Color" pada tahun 1982 oleh Nancy Ann Tape seorang psikolog yang mengklaim memiliki kemampuan melihat "aura" dari orang-orang sekitar. Menurut Carrol dan Jan (Soecipto, 2011: 5) menjelaskan anak Indigo adalah anak yang memiliki aura berwarna nila. Cara berpikirnya yang khas, pembawaan diri yang dewasa membuat anak Indigo tampil beda dengan anak sebayanya. Pancaran aura yang dimilikinya membawa kepada suatu karakteristik perilaku unik. Sedangkan menurut Dr. Erwin Kusuma dr. $\operatorname{SpKJ}(\mathrm{K})$ dalam (Soecipto, 2011: 7) menjabarkan Indigo bukan sebuah penyakit kelainan jiwa, indigo merupakan manusia yang memiliki kemampuan lebih dibandingkan manusia pada umumnya, seorang indigo perlu perhatian khusus dari lingkungannya agar terhindar stress dari kemampuan lebih anak indigo tersebut. Secara fisik dan mental anak indigo tidak memiliki perbedaan dengan manusia normal lainnya.

Perkembangan media massa begitu pesat, sehingga kita dapat mengetahui berita maupun acara mengenai manusia yang memiliki kekurangan dan kelebihan dari dalam dirinya. Salah satunya program reality show Indigo di Trans TV. Program yang menggambarkan kehidupan seorang Indigo dalam sehari-hari, namun program ini hanya bertahan satu tahun karena dalam tayangan tersebut hanya menampilkan sisi mistik dari fenomena indigo dibandingkan dengan kehidupan nyata Indigo tersebut. Program 
tersebut mendapat protes dari Komunitas Anak Indigo Indonesia karena dianggap telah melebih-lebihkan Indigo yang berdampak membuat persepsi masyarakat Indonesia semakin buruk terhadap Indigo. Protes tersebut ditanggapi oleh Komisi Penyiaran Indonesia (KPI) pada 18 Januari 2012. Tayangan "Indigo" dinilai tidak rasional, serta menampilkan tayangan Indigo dengan berbau mistik dan horror (KPI, 2012).

Fenomena indigo di Indonesia pun masih menjadi kontroversi. Ada pihak yang menganggap indigo merupakan suatu penyakit, namun ada juga yang berpendapat indigo merupakan anugrah yang diberikan oleh Tuhan kepada manusia. Hingga detik ini pun belum ada jumlah pasti berapa banyak populasi indigo di Indonesia. Itu terjadi karena masih banyak yang meragukan kaum Indigo. Stereotipe masyarakat Indonesia terhadap indigo masih memandang sebagai hal yang negatif seperti dapat melihat makhluk halus, dapat melihat masa lalu dan masa depan, dianggap gila, memiliki ruang lingkup sendiri, tak jarang dianggap seperti autis dan hal-hal yang dianggap aneh oleh orang banyak. Namun ketika dibawa ke psikiater seorang Indigo dianggap tidak memiliki gangguan jiwa ataupun masuk kedalam ketegori autis. Semua yang dialami indigo nyata, namun tidak dapat dibuktikan secara kasat mata. Ada beberapa karakteristik yang hanya dimiliki oleh seorang indigo, indigo bukan sebuah penyakit atau gangguan tetapi sebuah angurah dari tuhan yang harus dipergunakan dengan baik. "Permasalahan di Indonesia, banyak Indigo yang stress tidak dapat mengontrol dirinya akibat lingkungan yang meremehkan, mengejek, dan tidak mau menerima perbedaan yang dimiliki oleh seorang Indigo. Itulah yang perlu dibehani dari diri seorang Indigo agar dapat mengontrol dirinya sendiri. Permasalahan tersebut dapat berdampak buruk terhadap ruang lingkup interaksi sosial seorang indigo kepada orang lain." (Komunitas Indigo Indonesia, 2010).

Indonesia sendiri belum memiliki lembaga resmi negara yang merangkul kaum indigo, sehingga kaum indigo belum terlindungi secara hukum. Memiliki latar belakang dan keistimewaan yang sama, muncul komunitas yang merangkul kaum indigo. Salah satu komunitas yang peduli dengan keberadaan indigo adalah Komunitas Anak Indigo (KAI). Perkumpulan ini sudah berlangsung lama sekitar tahun 2012, namun baru memiliki nama resmi Komunitas Anak Indigo (KAI) sejak awal 2016. Pencetus Komunitas Anak Indigo tergerak hatinya untuk merangkul kaum indigo yang ada di Indonesia. Setiap tahun mengalami perkembangan yang baik, dan pada akhirnya komunitas anak indigo memiliki tempat riset khusus indigo yang diberi nama Indigo Research Centre Office yang bergerak dalam bidang penelitian indigo, dan konsultasi 
khusus anak indigo bagi orang tua yang memiliki anak indigo. Selain itu Komunitas Anak Indigo mendukung anggotanya untuk berkarya sesuai latar belakang kemampuannya, seperti membuat film, berbisnis, musisi, dan karya lainnya. Komunitas anak indigo sering membuat atau mengikuti kegiatan sosial yang ada di Indonesia. Tujuan akhir Komunitas Anak Indigo agar kaum indigo dapat diterima keberadaannya di masyarakat luas, karena kaum Indigo sama dengan manusia lainnya hanya memiliki kemampuan lebih yang tidak dimiliki oleh orang lain.

Kaum indigo merupakan makhluk sosial, mereka berinteraksi dengan orang lain dihubungankan dengan sebuah komunikasi. Kita berkomunikasi terutama untuk menyatakan dan mendukung identitas diri, untuk membangun kontak sosial dengan orang di sekitar kita, dan mempengaruhi orang lain untuk merasa, berpikir, atau berperilaku seperti yang kita inginkan (Mulyana, 2008: 4). Namun proses komunikasi yang dilakukan kaum indigo penulis pastikan mengalami hambatan yang muncul dari keraguan kaum indigo. Seorang indigo memiliki karakteristik introvert, hal tersebut terbentuk akibat pengalaman ejekan, penolakan dari lingkungan sekitar, sehingga seorang indigo cenderung menutup diri untuk tidak berkomunikasi dengan individu lain. Munculah rasa minder, ragu, malas untuk berkomunikasi dengan individu lain, sehingga hal tersebut menjadi hambatan seorang indigo dalam berkomunikasi. Mulyana (2008: 16) menjelaskan bahwa kebutuhan utama manusia adalah kebutuhan akan hubungan sosial yang ramah, yang hanya bisa terpenuhi dengan membina hubungan yang baik dengan orang lain. Hal tersebut berbanding terbalik dengan apa yang dirasakan oleh kaum indigo, kaum indigo memiliki kemampuan berbeda dengan anak atau orang seusianya, yaitu pengalaman Extra Sensory Perception (ESP), spiritual yang tinggi, dan rasionalis. Hal tersebut membuat kaum indigo mengkategorikan orang-orang dalam berkomunikasi.

Maka dari itu setiap orang memiliki konsep diri masing-masing, begitu juga dengan seorang indigo. Mereka memiliki konsep diri yang terbentuk oleh pengalaman komunikasi dan pandangan dari lingkungan sekitarnya seperti keluarga atau temantemannya. Pandangan dari lingkungan saat melakukan interaksi sangat membentuk konsep dirinya. Seperti halnya tidak sedikit seorang indigo menerima penolakan dari lingkungan karena ketika seorang indigo melihat makhluk halus dan menceritakan apa yang dia lihat kepada orang lain yang menganggap cerita itu adalah imajinasi atau halusinasi dari seorang indigo, sehingga orang yang tidak bisa menerima pernyataan dari seorang indigo tadi, menganggap mereka aneh dan membuat seorang indigo terkadang merasa tidak nyaman bahkan 
mengeluh mengapa diberikan kelebihan karunia yang tidak semua orang bisa memilikinya. Pada saat berinteraksi dengan orang lain, individu melihat pada dirinya tentang bagaimana cara orang lain menilai, memperlakukan dan berbuat terhadap dirinya. Pada saat penting itulah seseorang akan mengetahui posisi-posisi yang dibangun dan ditetapkan (Diniati, 2015). Dalam pergaulan kaum indigo baik di lingkungan keluarga maupun di lingkungan luar dibutuhkan kesiapan mental dan konsep diri.

Penelitian ini membahas konsep diri anggota Komunitas Anak Indigo (KAI). Fokus penelitian ini adalah bagaimana konsep diri anggota Komunitas Anak Indigo (KAI) dalam melakukan komunikasi antarpribadi. Tujuan dari penelitian ini adalah untuk menguraikan konsep diri anggota komunitas anak indigo dalam melakukan komunikasi antarpribadi yang berorientasi pada motif masa lalu, masa kini, dan masa akan datang.

\section{Komunikasi Antar Pribadi}

$$
\text { Pada dasarnya komunikasi }
$$

antarpribadi merupakan suatu proses pertukaran makna atau pesan antara orangorang yang saling berkomunikasi dalam konteks individu dengan individu. Komunikasi antarpribadi (interpersonal communication) adalah komunikasi antara orang-orang secara tatap muka, yang memungkinkan setiap pesertanya menangkap reaksi orang lain secara langsung, baik secara verbal ataupun nonverbal (Mulyana, 2008: 81).

\section{Konsep Diri}

Konsep diri adalah persepsi tentang diri; seseorang sendiri yang bersifat fisik, psikologis, maupun sosial; yang datang dari pengalaman dan interaksi seseorang dengan orang lain. Kecenderungan seseorang berperilaku sesuai dengan konsep dirinya disebut self fulfilling prophecy. Konsep diri memiliki dua kualitas atau valensi. Konsep diri mempengaruhi perilaku komunikasi kita, karena konsep diri mempengaruhi kepada pesan apa kita bersedia membuka diri, bagaimana mempersepsi pesan itu, dan apa yang kita ingat. Sukses komunikasi antarpribadi banyak bergantung pada kualitas konsep diri yaitu, konsep diri negatif dan positif. Konsep diri yang negatif sangat menganggu keberhasilan komunikasi antarpribadi. Orang yang mempunyai konsep diri negatif ditandai dengan ciri-ciri (Rakhmat, 2011: 103-104):

1. Tidak tahan kritik, mudah marah, beranggapan bahwa koreksi orang lain tentang dirinya adalah usaha untuk menjatuhkan dirinya.

2. Haus atau sangat responsif terhadap pujian, disisi lain sangat kritis dalam menilai orang lain serta tidak sanggup menerima kelebihan orang lain. 
3. Enggan berkompetensi dengan orang lain.

4. Cenderung merasa tidak disenangi, tidak diperhatikan serta tidak diterima oleh orang lain.

5. Bersikap pesimis dalam berkompetisi.

Menurut Jourard 1971 (Rakhmat, 2011: 205) konsep diri positif lahir dari pola perilaku komunikasi antarpribadi yang positif, yakni melakukan persepsi lebih cermat, dan mengungkap petunjuk-petunjuk yang membuat orang lain menafsirkan kita cermat pula. Komunikan yang berkonsep diri positif adalah orang yang "tembus pandang" (transparent), terbuka kepada orang lain. Ciri-ciri orang yang memiliki konsep diri positif antara lain (Rakhmat 2011: 104):

1. Mempunyai keyakinan terhadap kemampuannya untuk mengatasi berbagai masalah, bahkan ketika mengalami kegagalan.

2. Merasa sama atau setara dengan orang lain.

3. Menerima pujian tanpa rasa malu atau pura-pura rendah hati, serta menerima penghargaan tanpa rasa bersalah.

4. Memiliki kemampuan untuk terusmenerus memperbaiki diri sendiri serta menyadari kesalahan pribadi.

5. Menyadari bahwa setiap orang memiliki perasaan, keinginan dan perilaku yang tidak sepenuhnya disenangi oleh orang lain atau masyarakat.

\section{Indigo}

Indigo pertama kali diperkenalkan pada buku "Understanding Your Life Through Color" pada tahun 1982 oleh Nancy Ann Tape seorang psikolog yang mengklaim memiliki kemampuan melihat "aura" dari orang-orang sekitar. Menurut Carrol dan Jan (Soecipto, 2011: 5) menjelaskan anak Indigo adalah anak yang memiliki aura berwarna nila. Cara berpikirnya yang khas, pembawaan diri yang dewasa membuat anak Indigo tampil beda dengan anak sebayanya. Pancaran aura yang dimilikinya membawa kepada suatu karakteristik perilaku unik. Sedangkan menurut Dr. Erwin Kusuma dr. $\operatorname{SpKJ}(\mathrm{K})$ dalam (Soecipto, 2011: 7) menjabarkan Indigo bukan sebuah penyakit kelainan jiwa, indigo merupakan manusia yang memiliki kemampuan lebih dibandingkan manusia pada umumnya, seorang indigo perlu perhatian khusus dari lingkungannya agar terhindar stress dari kemampuan lebih anak indigo tersebut. Secara fisik dan mental anak indigo tidak memiliki perbedaan dengan manusia normal lainnya.

Indigo dalam kamus bahasa Indonesia berarti biru tua yang diperoleh dari tumbuhan nila atau ratum. Anak indigo adalah anak yang memiliki karakteristik yang berbeda dari anak-anak seusianya. Dalam diri anak indigo terdapat kelebihan- 
kelebihan dan kemampuan khusus yang tidak dimiliki oleh anak yang lainnya atau anak pada umumnya. Anak indigo memiliki sifat yang unik (Puguh, 2012: 64-67). Perbedaan anak indigo tidak hanya pada cahaya atau auranya saja, namun setelah diadakan beberapa tes, fungsi organ pada anak indigo, hasilnya mereka menunjukkan sistem kekebalan dan DNA yang lebih kuat, meskipun tergolong masih bayi. Anak indigo juga dikaitkan dengan indra keenam. Indra keenam merupakan kelebihan yang ada dalam diri seseorang yang tidak dimiliki oleh semua orang. Namun tidak semua orang yang memiliki indra keenam adalah indigo. Banyak orang yang memiliki persepsi salah seputar anak indigo, dikatakan anak indigo merupakan penyakit kelainan otak atau kelainan jiwa. Namun tidak ada bukti yang kuat menyatakan hal tersebut. Dalam hal ini, Badan Kesehatan Dunia (WHO) tidak mencantumkan anak indigo pada daftar penyakit anak atau cacat mental (Puguh, 2012: 104-105).

Terlahir dengan fisik sempurna, namun memiliki perbedaan, seperti anak indigo. Banyak orang yang memiliki persepsi salah seputar anak indigo, dikatakan anak indigo merupakan penyakit kelainan otak atau kelainan jiwa. Namun tidak ada bukti yang kuat menyatakan hal tersebut. Dalam hal ini, Badan Kesehatan Dunia (WHO) tidak mencantumkan anak indigo pada daftar penyakit anak atau cacat mental
(Puguh, 2012: 104-105). Kekuatan batin yang sangat tajam yang dimiliki oleh anak indigo memang akan berdampak bagi kehidupannya. Jika anak indigo dengan mudah melakukan komunikasi dengan orang lain tanpa membatasi lingkup bahasan yang dibahas, maka tanpa sadar anak indigo tersebut akan mengeluarkan kemampuannya. Beberapa kemampuan anak indigo akan membuatnya bertingkah aneh, hal ini akan menciptakan suatu opini di masyarakat yang berbeda-beda tentang tingkahnya (Puguh, 2012: 119-120).

\section{METODE PENELITIAN}

Penelitian ini menggunakan metode studi fenomenologi. Fenomenologi menurut Creswell (2010: 20) merupakan strategi penelitian dimana di dalamnya peneliti mengidentifikasikan hakikat pengalaman manusia tentang suatu fenomena tertentu Pertimbangan menggunakan penelitian ini dikarenakan fokus penelitian ini akan berpusat kepada anggota Komunitas Anak Indigo (KAI). Metode penelitian kualitatif adalah metode penelitian yang digunakan untuk meneliti pada kondisi objek yang alamiah, dimana peneliti adalah sebagai instrumen kunci, teknik pengumpulan data dilakukan secara trianggulasi, analisis data bersifat induktif, dan hasil penelitian lebih menekankan makna dari pada generalisasi (Sugiyono, 2014: 1). Menurut Patton (1980: 41) menyatakan penelitian kualitatif adalah 
untuk memahami fenomena yang sedang terjadi secara alamiah dalam keadaankeadaan yang sedang terjadi secara alamiah. Konsep ini lebih menekankan pentingnya sifat data yang diperoleh oleh penelitian kualitatif, yakni data ilmiah. Data ilmiah ini utamanya diperoleh dari hasil ungkapan langsung dari subjek peneliti. Teknik pengumpulan data dilakukan dengan cara focus group discussion (FGD), wawancara mendalam, observasi dan dokumentasi. Hasil data observasi disajikan dalam bentuk deskripsi. Sedangkan hasil wawancara disajikan dalam bentuk transkrip wawancara dan dokumentasi disajikan dalam bentuk gambar di lampiran. dengan lingkungan sosial, sehingga mampu membentuk konsep diri tertentu pada anggota Komunitas Anak Indigo, baik berupa konsep diri positif ataupun negatif yang sesuai dengan teori konsep diri menurut Supratman (2016: 42) menjelaskan bahwa konsep diri memiliki dua kualitas atau valensi, Konsep diri mempengaruhi perilaku komunikasi kita, karena konsep diri mempengaruhi kepada pesan apa kita bersedia membuka diri, bagaimana mempersepsi pesan itu, dan apa yang kita ingat. Sukses komunikasi antarpribadi banyak bergantung pada kualitas konsep diri yaitu, konsep diri negatif dan positif.

Tabel 1
HASIL

\section{PEMBAHASAN}

Penelitian
DAN

Penelitian $r$ ini
menjelaskan konsep diri
anggota Komunitas Anak
Indigo (KAI) melalui
pengalaman interaksi
dengan lingkungan sosial
atau yang lebih dikenal
dengan nama komunikasi
antarpribadi dalam orientasi
motif masa lalu, motif masa

Final Identification kini, dan motif masa akan datang. Setiap motif dibagi menjadi dua bentuk, yaitu pengalaman dan konsep diri. Pengalaman merupakan apa yang dialami anggota Komunitas Anak Indigo dalam berinteraksi

\section{Final Identification}

\begin{tabular}{|c|c|c|}
\hline \multirow{2}{*}{$\begin{array}{l}\text { Motif Masa Lalu } \\
\text { Anggota } \\
\text { Komunitas Anak } \\
\text { Indigo }\end{array}$} & Pengalaman & - Penerimaan Diri \\
\hline & Konsep Diri & $\begin{array}{l}\text { - Menutup Diri } \\
\text { - } \quad \text { Merasa Beda }\end{array}$ \\
\hline \multirow[t]{2}{*}{$\begin{array}{l}\text { Motif Masa Kini } \\
\text { Anggota } \\
\text { Komunitas Anak } \\
\text { Indigo }\end{array}$} & Pengalaman & $\begin{array}{ll}\text { - } & \text { Tempat Berkarya } \\
\text { - } & \text { Bertukar Pengalaman } \\
\text { - } & \text { Menambah Relasi } \\
& \text { Pertemanan } \\
\text { - } & \text { Edukasi Masyarakat } \\
\end{array}$ \\
\hline & Konsep Diri & - Peduli Sesama \\
\hline \multirow{2}{*}{$\begin{array}{l}\text { Motif Masa Akan } \\
\text { Datang Anggota } \\
\text { Komunitas Anak } \\
\text { Indigo }\end{array}$} & Pengalaman & - Merasa Seperti Keluarga \\
\hline & Konsep Diri & $\begin{array}{ll}\text { - } & \text { Introspeksi Diri } \\
\text { - } & \text { Religius }\end{array}$ \\
\hline
\end{tabular}

Sumber: Olahan Peneliti (2016)

Final identification akan menjelaskan pengalaman interaksi dan pembentukan konsep diri yang berorientasi pada motif masa lalu, masa kini, dan masa akan datang 
dari anggota Komunitas Anak Indigo. Lalu pengalaman tersebut membentuk konsep diri anggota Komunitas Anak Indigo. Pertama dari motif masa lalu anggota Komunitas Anak Indigo, dibagi menjadi dua bentuk yaitu pengalaman dan konsep diri. Pengalaman dalam motif masa lalu anggota Komunitas Anak Indigo yang dialami yaitu penerimaan diri. Pengalaman anggota Komunitas Anak Indigo mengalami pengalaman bentuk penolakan maupun penerimaan anggota Komunitas Anak Indigo di lingkungan sosialnya, sehingga hal tersebut dikerucutkan dalam konteks penerimaan diri anggota Komunitas Anak Indigo di lingkungan sosial. Pengalaman masa lalu tersebut membentuk konsep diri anggota Komunitas Anak Indigo menjadi seorang yang menutup diri dan merasa beda dengan lingkungan sosial.

Motif masa kini anggota Komunitas Anak Indigo, merupakan hal- hal yang dialami pada masa kini oleh anggota Komunitas Anak Indigo dari pengalaman yang akan membentuk konsep diri anggota Komunitas Anak Indigo. Motif masa kini anggota Komunitas Anak Indigo dibagi dua bentuk yaitu pengalaman dan konsep diri. Pengalaman dalam motif masa kini yang dialami anggota Komunitas Anak Indigo yaitu tempat berkarya, bertukar pengalaman, menambah relasi pertemanan, dan edukasi masyarakat. Pengalaman masa kini tersebut membentuk konsep diri anggota Komunitas Anak Indigo menjadi peduli sesama.

Motif masa akan datang anggota Komunitas Anak Indigo, merupakan hal-hal yang diharapkan atau gambaran di masa akan datang sehingga membentuk konsep diri anggota Komunitas Anak Indigo. Motif masa akan datang anggota Komunitas Anak Indigo dibagi dua bentuk yaitu pengalaman dan konsep diri. Pengalaman masa akan datang dari anggota Komunitas Anak Indigo yaitu merasa seperti keluarga. Sehingga pengalaman merasa seperti keluarga membentuk konsep diri anggota Komunitas Anak Indigo menjadi lebih intorspeksi diri dan religius.

Selanjutnya peneliti akan membahas motif dalam orientasi masa lalu, masa kini, dan masa akan datang serta pengalaman interaksi dari anggota Komunitas Anak Indigo secara mendalam. Motif dan pengalaman khususnya pengalaman interaksi dengan lingkungan sosial dari anggota Komunitas Anak Indigo menjadi landasan atau alasan kuat para anggota Komunitas Anak Indigo pada akhirnya memilih untuk bergabung dengan Komunitas Anak Indigo untuk menjadi tempat bersosialisasi dengan orang lain. Berikut ini merupakan model mengenai motif anggota Komunitas Anak Indigo. 
Komunitas Anak Indigo tidak dapat diterima dalam lingkungan sosial, sehingga anggota Komunitas Anak Indigo membutuhkan
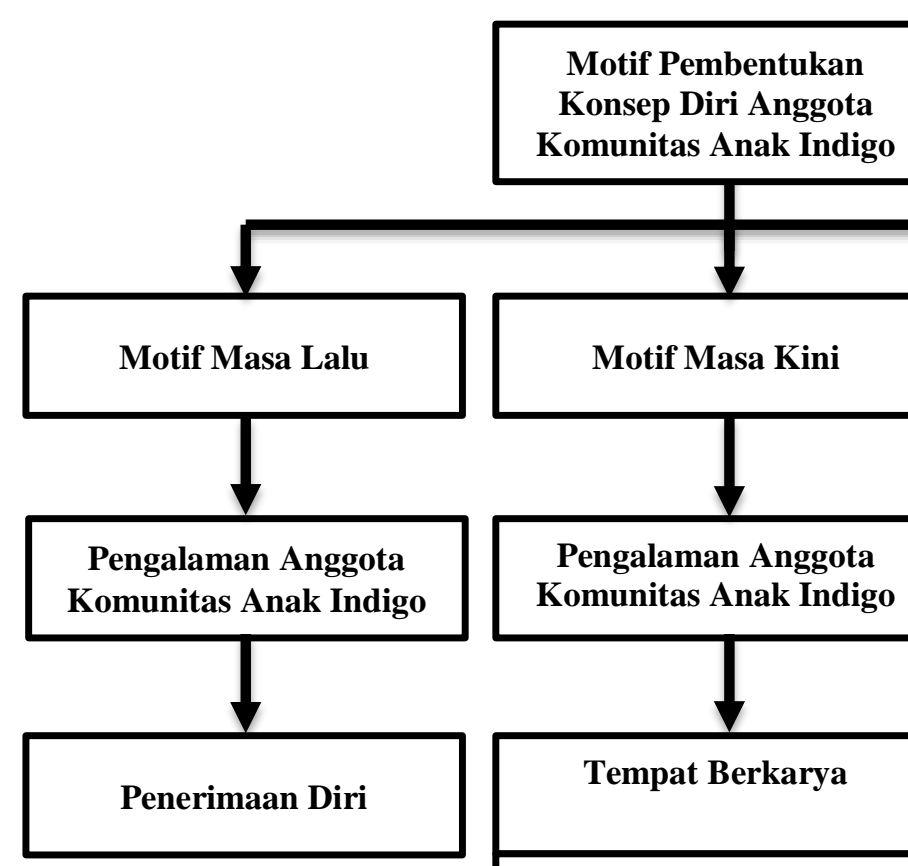

Konsep Diri Anggota
Komunitas Anak Indigo

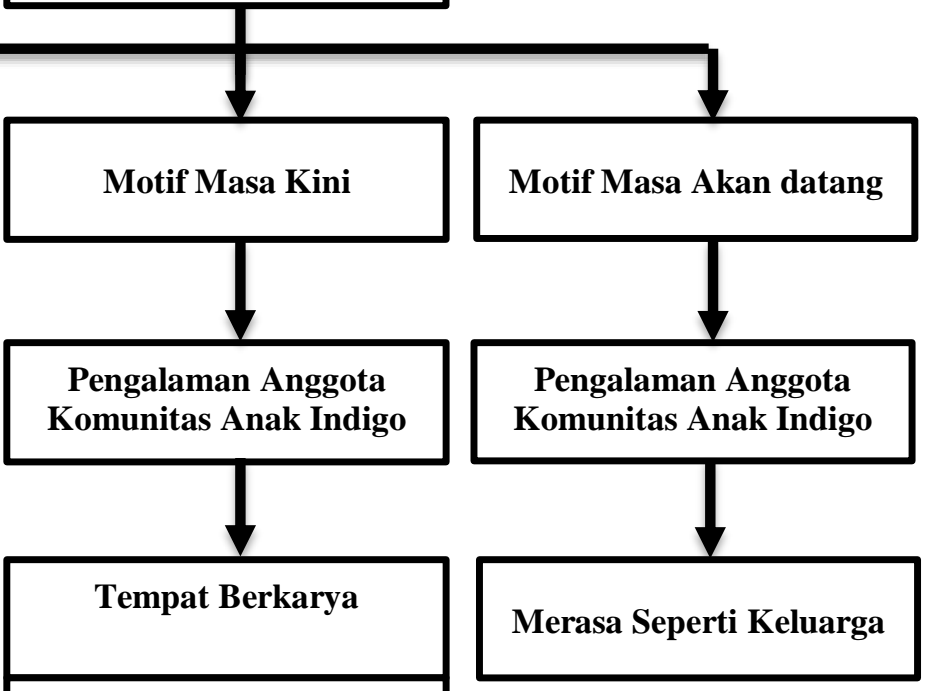

\begin{tabular}{|c|}
\hline Bertukar Pengalaman \\
\hline Menambah Relasi \\
Pertemanan \\
\hline Edukasi Masyarakat \\
\hline
\end{tabular}

teman atau lingkungan yang menerima

Gambar 1

Model Motif Anggota Komunitas Anak Indigo

Sumber: Olahan Peneliti(2016)

Model pada gambar menggambarkan bahwa pada motif masa lalu anggota Komunitas Anak Indigo mengalami pengalaman penerimaan diri, bentuk penolakan maupun penerimaan anggota Komunitas Anak Indigo di lingkungan sosialnya, sehingga hal tersebut dikerucutkan dalam konteks penerimaan diri anggota Komunitas Anak Indigo di lingkungan sosial. Penolakan terjadi akibat anggota dirinya sebagai indigo. Lalu Penerimaan terjadi dalam lingkungan keluarga anggota Komunitas Anak Indigo, sehingga anggota 1 Komunitas Anak Indigo merasa dirinya diterima dalam lingkungan keluarga dan mencari lingkungan serupa namun diluar lingkungan keluarga. Sehingga motif penerimaan diri menjadi motif masa lalu anggota Komunitas Anak Indigo.

Motif masa kini anggota Komunitas Anak Indigo mengalami pengalaman komunitas sebagai tempat berkarya, anggota Komunitas Anak Indigo sangat 
membutuhkan termpat berkarya untuk motif masa kini anggota Komunitas Anak perkembangan dari individu anggota Indigo.

Komunitas Anak Indigo itu sendiri, selain itu Motif masa akan datang anggota untuk menunjukan sebagai indigo mampu berkarya layaknya manusia pada umumnya. Lalu bertukar pengalaman, anggota Komunitas Anak Indigo menilai bertukar pengalaman merupakan pengalaman yang dirasakan masa kini bersama komunitas. Diluar lingkungan komunitas para anggota Komunitas Anak Indigo tidak bisa melakukan bertukar pengalaman dengan orang lain karena adanya bentuk penolakan dari lingkungan sosialnya. Selanjutnya menambah relasi pertemanan, anggota Komunitas Anak Indigo merasakan pengalaman berada di komunitas saat masa kini menambah relasi pertemanan. Dalam komunitas para anggota Komunitas Anak Indigo mampu bertambah teman yang sesama indigo ataupun non indigo, tidak seperti dalam lingkungan sosial pada umumnya para anggota Komunitas Anak Indigo sangat sulit mendapatkan teman yang mau menerima mereka sebagai indigo. Terakhir yaitu edukasi masyarakat, anggota Komunitas Anak Indigo berada di komunitas saat ini melakukan pengalaman edukasi masyarakat sebagai bentuk pencerdasan kepada masyarakat umum mengenai indigo, agar indigo mampu diterima oleh masyarakat umum. Sehingga motif tempat berkarya, bertukar pengalaman, menambah relasi pertemanan, dan edukasi masyarakat menjadi Komunitas Anak Indigo mengalami pengalaman mendapatkan dirinya merasa seperti keluarga berada dalam komunitas, dalam artian lingkungan komunitas layaknya seperti keluarga yang menerima, saling mengerti anggota Komunitas Anak Indigo layaknya mereka berada dalam sebuah keluarga. Hal-hal tersebut berdampak baik bagi anggota Komunitas Anak Indigo untuk pengalaman di masa akan datang. Sehingga motif merasa seperti keluarga menjadi motif masa akan datang anggota Komunitas Anak Indigo. Berdasarkan motif dan pengalaman anggota Komunitas Anak Indigo tersebut berhasil membentuk lima konsep diri anggota anggota Komunitas Anak Indigo seperti menutup diri, merasa beda, peduli sesama, introspeksi diri, dan religius.

Konsep diri anggota Komunitas Anak Indigo menjadi seorang yang menutup diri ketika anggota Komunitas Anak Indigo menilai dirinya dalam pengalaman masa lalu sering mendapatkan pengalaman intimidasi, penindasan, disudutkan, ejekan, dan disebut orang aneh oleh lingkungan sosialnya, khususnya lingkungan pertemanan. Lalu pembentukan konsep diri anggota Komunitas Anak Indigo lainnya yaitu merasa beda dengan lingkungan sosial. Pengalaman dalam masa lalu anggota Komunitas Anak Indigo yang buruk membentuk konsep diri 
mereasa beda, karena anggota Komunitas Anak Indigo merasa dijauhi lingkungan sosial, dikucilkan lingkungan sosial, dan orang-orang menghindar dari anggota Komunitas Anak Indigo. Pengalaman tersebut membentuk konsep diri anggota Komunitas Anak Indigo, konsep diri yang terbentuk yaitu anggota Komunitas Anak Indigo yang menutup diri dari lingkungan sosial dan merasa beda dengan lingkungan sosialnya. Pengalaman dalam masa lalu anggota Komunitas Anak Indigo yang buruk membentuk konsep diri merasa beda, karena anggota Komunitas Anak Indigo merasa dijauhi lingkungan sosial, dikucilkan lingkungan sosial, dan orang-orang menghindar dari anggota Komunitas Anak Indigo. Lalu pengalaman masa kini bersama komunitas membentuk anggota Komunitas Anak Indigo menjadi peduli sesama tanpa memandang indigo atau bukan indigo, melalui pengalaman edukasi masyarakat, tempat berkarya, menambah relasi pertemanan mampu membentuk konsep diri anggota Komunitas Anak Indigo menjadi peduli sesama. Selanjutnya pengalaman masa akan datang bersama komunitas membentuk konsep diri anggota Komunitas Anak Indigo menjadi seorang yang lebih introspeksi diri dan religius. Anggota Komunitas Anak Indigo menilai bahwa dirinya perlu lebih introspeksi diri di masa akan datang sebagai indigo, karena di masa lalu dan masa kini mengalami kendala- kendala dalam mengendalikan diri sebagai indigo. Lalu pembentukan konsep diri menjadi seorang yang religius terbentuk akibat anggota Komunitas Anak Indigo menilai dirinya sadar sebagai umat beragama, kemampuan yang diberikan oleh Tuhan kepada anggota Komunitas Anak Indigo akan kembali lagi kepada Tuhan. Sehingga membuat anggota Komunitas Anak Indigo tidak sombong dan lupa diri atas kemampuannya.

Pembentukan konsep diri anggota Komunitas Anak Indigo terbentuk dari dirinya sendiri melalui pengalamanpengalaman interaksi pada masa lalu, masa kini, dan masa akan datang. Pengalaman tersebut hadir dari significant others meliputi lingkungan keluarga, dan reference group meliputi lingkungan pertemanan serta komunitas. Maka dari itu, terbentuklah konsep diri positif atau negatif dari anggota Komunitas Anak Indigo. Berikut ini model konsep diri anggota Komunitas Anak Indigo.

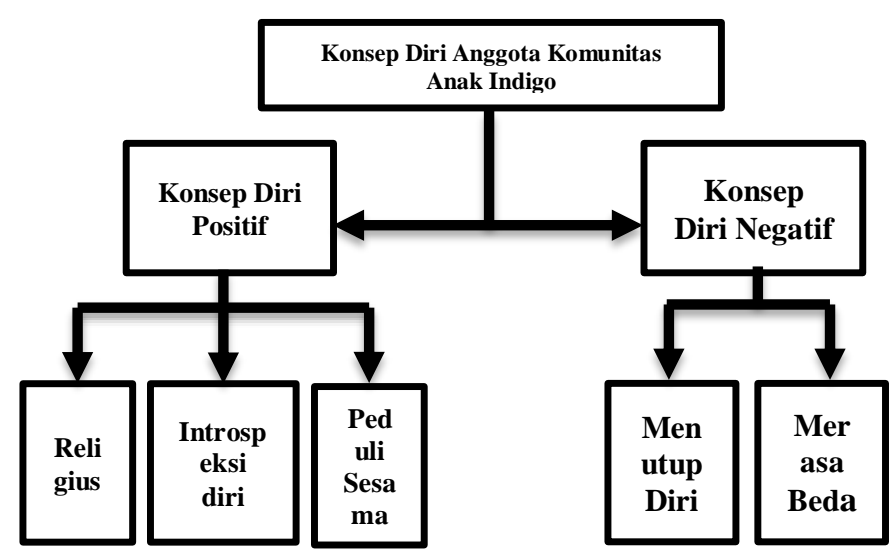

\section{Gambar 2}

Model Konsep Diri Anggota Komunitas Anak Indigo Sumber: Olahan Peneliti(2016) 
Model pada gambar 2 karena anggota Komunitas Anak Indigo menggambarkan pembentukan konsep diri menilai dirinya perlu mengendalikan diri dan anggota Komunitas Anak Indigo. Konsep memperbaiki diri dalam segi kekuatan diri diri anggota Komunitas Anak Indigo ataupun berpikir untuk menjadi orang yang terbentuk berdasarkan pengalaman interaksi lebih baik kedepanya sebagai indigo. Serta dengan lingkungan sosial dalam masa lalu, konsep diri peduli sesama terbentuk karena masa kini, dan masa akan datang. Konsep diri meliputi apa yang dipikirkan dan apa yang dirasakan temtang diri sendiri. Konsep diri memiliki dua valensi atau kualitas, yaitu konsep diri positif dan negatif. Konsep diri terbentuk sangat berpengaruh besar dari significant others dan reference group.

Pembentukan konsep diri anggota Komunitas Anak Indigo melalui tiga bentuk motif masa, yaitu motif masa lalu, motif masa kini, dan motif masa akan datang. Konsep diri dari anggota Komunitas Anak Indigo berbentuk konsep diri positif dan negatif. Anggota Komunitas Anak Indigo memiliki bentuk konsep diri positif religius, introspeksi diri, dan peduli sesama. Sedangkan konsep diri negatif dari anggota Komunitas Anak Indigo berupa menutup diri dan merasa beda. Konsep diri religius terbentuk karena anggota Komunitas Anak Indigo menilai dirinya sebagai umat beragama perlu sadar bahwa kemampuan indigo yang dimiliki merupakan pemberian dari Tuhan dan akan kembali kepadanya, sehingga anggota Komunitas Anak Indigo tidak boleh sombong dan lupa diri, maka dari itu perlu mendekatkan diri kepada Tuhan. Lalu konsep diri introspeksi diri terbentuk anggota Komunitas Anak Indigo menilai dirinya perlu peduli sesama tanpa memandang orang tersebut indigo atau bukan, hal tersebut terbentuk berdasarkan pengalaman anggota Komunitas Anak Indigo berada dalam komunitas yang selalu berhubungan dengan orang lain seperti komunitas sebagai tempat berkarya, bertukar pengalaman, menambah relasi pertemanan dan edukasi masyarakat. Maka dari itu konsep diri religius, introspeksi diri, dan peduli sesama menjadi konsep diri yang berbentuk positif. Konsep diri menutup diri terbentuk karena anggota Komunitas Anak Indigo menilai dirinya selalu mendapatkan intimidasi, penindasan, disudutkan, ejekan, dan disebut gangguan jiwa, sedangkan konsep diri merasa beda para anggota Komunitas Anak Indigo menilai dirinya selalu dijauhi lingkungan pertemanan, dikucilkan lingkungan pertemanan, dan lingkungan sosial menjauhi anggota Komunitas Anak Indigo. Maka dari itu konsep diri menutup diri dan merasa beda menjadi konsep diri yang berbentuk negatif. Berdasarkan model di atas pembentukan konsep diri anggota Komunitas Anak Indigo terbentuk menjadi konsep diri positif dan 
negatif. Konsep diri positif yang terbentuk adalah peduli sesama, introspeksi diri, dan religius, sedangkan konsep diri negatif yang terbentuk adalah menutup diri, dan merasa beda. Pembentukan konsep diri anggota Komunitas Anak Indigo dipengaruhi dari dalam maupun lingkungan luar dirinya.

\section{SIMPULAN}

Berdasarkan hasil penelitian yang peneliti lakukan melalui tahap focus group disscussion (FGD), wawancara mendalam, dan observasi yang peneliti paparkan di bab sebelumnya, maka peneliti dapat simpulkan. Bahwa konsep diri merupakan gambaran yang dimiliki seseorang tentang dirinya, yang dibentuk melalui pengalamanpengalaman yang diperoleh dari interaksi dengan lingkungan. Konsep diri merupakan aspek penting dalam diri seseorang, karena konsep diri seseorang merupakan kerangka acuan dalam berinteraksi dengan lingkungan.

Pembentukan konsep diri anggota Komunitas Anak Indigo (KAI) terbentuk melalui pengalaman interaksi dengan lingkungan sosial, seperti lingkungan keluarga sebagai faktor significant others, lingkungan pertemanan, dan lingkungan komunitas sebagai faktor reference group dalam motif masa lalu, masa kini, dan masa akan datang. Pada motif masa lalu anggota Komunitas Anak Indigo (KAI) membentuk konsep diri negatif, anggota Komunitas Anak Indigo (KAI) menilai dirinya menjadi mentuo diri dan merasa beda dengan lingkungan sosialnya, konsep diri tersebut terbentuk melalui pengalaman interaksi dalam penerimaan diri. Lalu pada motif masa kini anggota Komunitas Anak Indigo (KAI) membentuk konsep diri positif, anggota Komunitas Anak Indigo (KAI) menilai dirinya menjadi peduli sesama, konsep diri tersebut timbul akibat pengalaman interaksi tempat berkarya, bertukar pengalaman, menambah relasi pertemanan, dan edukasi masyarakat. Terakhir pada motif masa akan datang anggota Komunitas Anak Indigo (KAI) membentuk konsep diri positif, anggota Komunitas Anak Indigo (KAI) menilai dirnya menjadi lebih introspeksi diri, dan menjadi religius, konsep diri tersebut terbentuk timbul akibat pengalaman interaksi merasa seperti keluarga.

Sehingga anggota Komunitas Anak Indigo (KAI) memiliki konsep diri positif maupun negatif, tergantung pada lingkungan anggota Komunitas Anak Indigo (KAI) berada. Anggota Komunitas Anak Indigo (KAI) menilai keberadaan mereka dalam Komunitas Anak Indigo (KAI) mengalami perubahan ke arah yang lebih baik dari berbagai aspek kehidupan.

\section{DAFTAR PUSTAKA}

Creswell, J. W. (2010). Research design (pendekatan kualitatif, kuantitaif, dan mixed).

Yogyakarta: Pustaka Pelajar.

Diniati, Anisa. (2015).Makna Konsep Diri Mantan Anak Jalanan (Studi Fenomenologi 


\section{Pada Mantan Anak Jalanan Di Daerah}

Sukajadi Kota Bandung). Bandung:

Jurnal Kajian Komunikasi Universitas

Padjadjaran Vol.3 No.1

Komisi Penyiaran Indonesia. (2012). Demi Frekuensi Milik Publik. Indonesia 2012.

Diakses dari http://kpi.go.id/download/buku/demi_f rekuensi_milik_publik_2012_FINAL.p df pada hari Sabtu, 20 Agustus 2016 pukul 09.43 WIB

Komunitas Indigo Indonesia. (2010). Apakah Anak Anda Indigo. Diakses dari

https://komunitasindigoindonesia.wordpress. com/2010/01/27/apakah anak-andaindigo/ pada hari Minggu, 21 Agustus 2016 pukul 08.20 WIB

Mulyana, Deddy. (2008). Ilmu Komunikasi Suatu Pengantar. Bandung: PT RemajaRosdakarya.

Patton, M.Q. (1980). Qualitative Evaluation Methods. California: SAGE Publications.

Puguh, Omah. (2012). Buku Lengkap Tentang Anak Indigo. Jogjakarta: Flashbooks.

Rakhmat, Jalaluddin. (2011). Psikologi Komunikasi. Jakarta: PT Remaja Rosdakarya.

Soecipto, Nur Alam. (2011). Rahasia Besar Anak Indigo. Jogjakarta: Azna Books.

Sugiyono. (2014). Memahami Penelitian Kualitatif. Bandung: Alfabeta.

Supratman, Mahadian. (2016). Psikologi Komunikasi. Yogyakarta: Deepublish 